\title{
Sexual Perception of Young Lebanese Students
}

\author{
${\text { Ghada Bteich}{ }^{1}, \text { Mariana Hajj }^{1} \text {, Eliane Accaoui }}^{2}$, Abir El Abed ${ }^{1}$ \\ ${ }^{1}$ Faculty of Public Health, Lebanese University, Branch V, Saida, Lebanon \\ ${ }^{2}$ Faculty of Human Science, Lebanese University, Dekkwayne, Lebanon \\ Email:drghadabteich@gmail.com,hajj.mariana@hotmail.com, elianeaccaoui@hotmail.com,abir_abed@hotmail.com
}

How to cite this paper: Bteich, G., Hajj, M., Accaoui, E. and El Abed, A. (2017) Sexual Perception of Young Lebanese Students. Health, 9, 299-316. https://doi.org/10.4236/health.2017.92021

Received: April 28, 2016

Accepted: February 18, 2017

Published: February 21, 2017

Copyright $\odot 2017$ by authors and Scientific Research Publishing Inc. This work is licensed under the Creative Commons Attribution International License (CC BY 4.0).

http://creativecommons.org/licenses/by/4.0/ (c) (i) Open Access

\begin{abstract}
This article presents the sexual perception of young Lebanese students. We hypothesized that, in Lebanon and the Arab countries, premarital sex is forbidden by most cultures because of conservative societies and backgrounds. Sexuality lives as a "myth" in these conservative societies. We examined the influence of demographics and genders among a group of 706 Lebanese university students, from public and private universities, as well as the fluctuation of sexual beliefs and practices, based on their gender, demographics and social pressure. The method used was a questionnaire collected form $\mathrm{n}=706 \mathrm{stu}-$ dents, 446 females and 260 males. The female population of our sample is $62.9 \%$ of the total volunteers while the male population is $36.7 \%$. They come from different religions (Christian, Muslim, Druze and Other), between May 2015 and December 2015. Quantitative significant results: 1) A non-conformity with the social and demographic pressure and an openness of the new generations. Similarly, it shows more permissiveness in flirting. Even though, parts of the negative answers were significantly linked to understanding the rules of prohibited sex (NO 32.4\% for belief and NO 34.5\% for practice); 2) the reality of Lebanese youth, their integrity in engaging in a relationship, and their true daily happening of social and peer pressure; 3) An opening to a natural outlook of sexual life, (25.5\%) with reluctance on dating (51.1\%); 4) An important significance is showed in the percentage between beliefs and practice: $18 \%$ in belief and $78.3 \%$ in practice (Q1) and $34.2 \%$ in belief and $60.8 \%$ in practice $(\mathrm{Q} 2)$ emphasizing on the reality of sexual engagement within Lebanese youth; 5) However, reluctance in engaging in sexual activity and attachment and fear to social sanctions toward premarital sex and agreeing on abstinence before marriage. Quantitative findings supported the lack of sexual education and the prevalence of religious and social norms. This article examines Young Lebanese adolescents do not always have the same views neither the same patterns of sexual behaviors between men and women. Education and awareness are the keys to a healthy sexual life. Specifically, it considers the way they receive their sexual education, the acceptance and refusal of differences between genders, beliefs and practices. It becomes a real challenge
\end{abstract}


when it comes to early learning and education, openness, and real communication of sexual life, being a natural part of life, with honesty and transparency.

\section{Keywords}

Young Lebanese Adolescents, University Students, Sexuality, Perception, Premarital Sex, Sex Education, Dating

\section{Introduction}

Sexuality among youth has been a largely discussed and controversial issue across the world. It is a subject that interested and puzzled mankind since the beginning of history, namely, the way people conceive sexuality and practice it.

Throughout the centuries, after Adam and Eve, sexuality has evolved, especially that of young people. Critical events have had a hand in shaping the history of sexual knowledge and practices among them. For example, the "sexual revolution" in Berlin, in the 1920's, was a revolution of attitudes and behaviors. The entertainment field, (movies, theater, art, music and journalism) exposed a fully liberate sexual freedom and practices first seen in Europe [1].

In Russia, in the $19^{\text {th }}$ century, the homosexuality was illegal. In the 1910 's and early 1930's, in the Bolshevik era, changes were observed regarding free divorce and abortion, permitting prostitution and male homosexuality. Men and women became equal under law. All references to sex practices such as sodomy or other forms of sexual practices were removed from the Criminal Code in 1922, and considered as "natural". Sexual relationships were a freedom of choice. The changes of the revolution meant to transform society. But the country was too poor to sustain socialism because of the lack of economic development. When Stalin came to power, the homosexuality law was reinstituted. Homosexuals were driven back to prisons [2].

Likewise, a national crisis that occurred in France in May 1968 was intended for sexual liberation. It brought a change of behavior among the people, shaping new models in sexuality-related beliefs and practices. This sexual revolution was a social movement from the 1960s until the 1980s. It included increased acceptance of sex outside the traditional heterosexual, monogamous relationships. Public nudity, premarital sex, homosexuality, contraception and usage of pills, as well as abortion, were normalized [3].

In the United States of America, the premarital virginity was not a rule much before the sexual liberation that took place in the 1960's by the usage of the birth control pill. It allowed women to be in control of their pregnancies and created a feeling of freedom. The sexual revolution of young women benefited men equally, by lowering the risk of accidental pregnancies and unwanted fatherhood [4].

Nowadays, in the United States, 46 percent of high school students and 62 percent of high schools seniors have had sexual intercourse. Teen sexuality begins almost at the same age in the industrialized countries, depending on so- 
cioeconomic status, race and ethnicity, family structure, life and education aspirations. Sexual activity is a natural process for building future healthier relationships, postponing marriage and unwanted pregnancies [5].

In Lebanon and the Arab countries, premarital sex is forbidden by most cultures because of conservative societies and backgrounds. Sexuality lives as a "myth" in these conservative societies. Psychologically and physically speaking, sex is a need for humans due to their hormones (either men or women) it releases pressure and keeps people mentally healthy, by realizing there is no harm it as long as it's a healthy and stable relation [6].

Egyptian American journalist Mona Eltahawy, in her book "Headscarves and Hymens. Why the Middle East Needs a Sexual Revolution" published in June 2015, indicates the importance of conservative Egyptian society during the eighteen historic days of women protesters camping in Tahrir Square in January 2011. Those women apparently were violating their family and society rules and codes. They were judged by the media by doing drugs and having sex in the tents [7].

As mentioned in the book, these women were arrested, "were beaten, prodded with electric shock batons, subjected to strip searches, forced to submit to 'virginity tests,' and threatened with prostitution charges." She also mentioned the female genital mutilation (FGM), practiced on young girls and legalized under medical practice [8].

Arab women have a long way to express their "sexual liberation and revolution". It involves religion practices and beliefs supported by conservative societies. How could she be liberated from the "hypocrisy" imposed by these backgrounds? How could she become a consistent, active, autonomic family member if her voice is never heard?

Many studies have been done in the Middle East, considering sex as a taboo and forbidden subject. The cause is mainly the lack of sexual education and the prevalence of religious and social norms.

\subsection{Focus of the Study}

The purpose of the study is to encompass conceptions on sexuality among young Lebanese men and women, as well as contradictions between their sexual beliefs and practices based on their gender, demographics and social pressure. This study examines the influence of demographics and genders among a group of Lebanese university students, from public and private universities, as well as the fluctuation of sexual beliefs and practices.

Young Lebanese adolescents do not always have the same views neither the same patterns of sexual behaviors between men and women. Education and awareness are the keys to a healthy sexual life [9].

Problems arise when they learn about it, the way they receive their sexual education, the acceptance and refusal of differences between genders, beliefs and practices. What happens when premarital sex is forbidden by the family and the society? What are the motives of the family that help shape the sexual life of the youth? Why is sexual life labeled as "congruent" or "incongruent" in our society 


\subsection{Ethical Framework and Considerations of the Study}

We respected the ethics and value of the clinical research by enhancing knowledge deriving from the research. We implemented a rigorous methodology for scientific validity, integrity and consistency. Subjects have their privacy protected at all time of the study.

In assessment and interpretation, we followed the practical international guidance principles. We insured social value by determining our local community from which our participants are enrolled. The importance of the study would be to develop new questionings about youth sexuality in Lebanon and to be extended to the Arab countries. It would have a greater social value if results and interpretations are translated in Arabic language. It could be distributive within the community as an additional significant resource for sexual education among youth.

\section{Methodology}

The root of the study arises from the contradiction between beliefs and practices in active sexual life before marriage. The proposed methodology principle is followed.

The data was collected through a qualitative questionnaire of 18 questions. Some of the questions were drawn from the WHO site example.

(http://www.who.int/reproductivehealth/fr/) The rest of the questions were proposed by the authors upon the hypothesis of the study: "to what extent the relationship is consistent between the practices and beliefs of young Lebanese". The questionnaire was not validate.

A total of 709 students have accepted to participate in the study. They were randomly selected from several public and private universities during the academic year 2014/2015. They were selected from different majors such as engineering, medicine, accounting and business, architecture, nursing, physiotherapy, literature, law, advertising and marketing, science, human resources, interior design, computer science, and psychology. We took them from different disciplines to sufficiently preserve optimal diversity within the collected data required for subsequent analysis. They completed the questionnaire voluntarily and received no remuneration. They were informed about the purpose of the study, and that their responses would be confidential and anonymous.

The questions were formulated as follow:

Young people do not always have the same views on the relations between men and women.

For each question, tell me if you agree or not.

O One answer was for: "BY BELIEF" (depending on what you believe);

o And the second one was for: "PRACTICALLY" (depending on what you practice).

We had almost a 5\% of "No answer" to many of the questions. 
We will be introducing the main items of the questionnaire.

The questions $1,2,3,7,11,14,15$ and 16 are inquiring about relationships and engaging in an active sexuality before marriage.

1. It is good that the boys and girls who are not married could be dating.

2. It is good that the boys and girls kiss, hug and touch each other's.

3. There's no harm if boys and girls who are not married have sex, if they are in love.

7. A boy and a girl should have sex before becoming engaged to see if they are made for each other's.

11. Flirting without intercourse before marriage does not affect the honor of the girl (Question for Girls).

14. It's good to have one-night stands.

15. Boys and girls may have sex if they use means to prevent pregnancy.

16. We should be in love before having sex.

The questions 4, 5 and 6, are related to family and social pressure, depending on demographics and backgrounds.

4. A boy will not respect a girl who accepts to have sex. (Question for Boys)

5. Most girls who have sex before marriage regret it afterwards. (Question for Girls)

6. Most of the boys who have sex before marriage regret it (Question for Boys)

The following questions $8,9,10,11,12$ and 13 , raise the main issue of virginity in Lebanon. Lebanese men prefer to marry a virgin girl, reason why women who had premarital sex to hymenoplasty.

8. Girls should remain virgins until marriage. (Question for Girls)

9. Is the virginity the flag bearer of the honor of the girl and the family? (Question for Girls)

10. The hymen is the guarantor of the total faithfulness for the future husband. (Question for Girls)

12. Restorative surgery of the hymen on the wedding eve is a good resolution.

13. The boys should remain virgins until marriage. (Question for Boys)

Talking about sexuality without prejudice, with acceptance of their knowledge, practice and problems they encounter.

17. I express my opinion regarding sexuality freely in society.

18. I express my opinion regarding sexuality freely with family.

\section{Data Pre-Processing and Tool Used}

Data were collected through a questionnaire of eighteen questions, by a weblinked form and printed ones. The research timeline started in May 2015 and ended in December 2015.

Before analyzing the data, we used a technique to enhance the accuracy and the reliability of the extracted information. It consists of deleting inputs having a predefined number of questions without answers. Therefore, the results presented are done using all of the 706 vectors of answers. Data were coded and 
processed into SPSS, a statistical package system. The data were explored both for their descriptive statistics (i.e. percentage distributions, and frequency distributions) and inferential statistics (Pearson Chi-square test of independence). A paired T-test was run on the sample to determine whether there was a statistically significant difference between the "By belief" and "In practice" answers. Results were analyzed and summarized, in order to draw conclusions and make recommendations.

\section{Results}

The sample, 706 young Lebanese university students, was chosen randomly from different universities. The questionnaire was answered by a total of 706 young Lebanese university students, 446 females and 260 males. The female population of our sample is $62.9 \%$ of the total volunteers while the male population is $36.7 \%$. They come from different religions (Christian, Muslim, Druze and Other). The demographic distribution of the sample is shown in see Table 1.

We classify the questions by themes, and discuss the similarities and contradictions between beliefs and practices. We have run a paired T-test on the sample to determine whether there is a statistically significant difference between the "By belief" and "In practice" answers. The null and alternative hypotheses are as followed:

- $\mathrm{H}_{0}$ : the null hypotheses states that there is no difference between the answers of "By belief" and "In practice". By default, the null hypothesis is valid.

- $\mathrm{H}_{\mathrm{a}}$ : the alternative hypotheses states that there is a difference between the answers of "By belief" and "In practice".

The probability of type I $(\alpha)$ is set to 0.05 . It represents the probability of incorrectly reject the null hypothesis $\mathrm{H}_{0}$. The probability of type II $(\beta)$ is the failure to reject the null hypothesis when it is false.

The decision rule of acceptance or rejection of $\mathrm{p}$-value is as followed:

- p-value $<\alpha($ i.e. p-value $<0.05)$ than we conclude that there is a statistically significant difference, for the same questions, between the answers of "by belief" and "in practice".

- $\mathrm{p}$-value $>\alpha($ i.e. $\mathrm{p}$-value $>0.05)$ than we conclude that the observed difference between the answers of "by belief" and "in practice" are not statistically significant.

- Theme 1. Premarital sex and the before marriage issues adolescents' face.

Questions "1, 2, 3, 7, 14, 15 and 16", show that, for many young people, sexuality is approached with an open mind (see Table 2). They are responding to a natural sexual impulse, allowing it in their life with acceptance of equality between genders. It involves a decision on disposing of their young body and feelings, with acceptance of sexual freedom within one's limits. They are prepared to

Table 1. Demographic distribution of the sample.

\begin{tabular}{ccccc}
\hline Beirut & Mount Lebanon & North & South & Bekaa \\
\hline $19.6 \%$ & $44.3 \%$ & $6.2 \%$ & $25.3 \%$ & $2.1 \%$ \\
\hline
\end{tabular}


Table 2. Theme 1 questions and the percentage distribution of the obtained answers.

\begin{tabular}{lcc}
\hline \multicolumn{1}{c}{ Question number } & By belief & Practically \\
\hline $\begin{array}{l}\text { 1. It is good that the boys and girls who are not } \\
\text { married could be dating }\end{array}$ & YES: $86.1 \%$ & YES: $78.5 \%$ \\
$\begin{array}{l}\text { 2. It's good that the boys and girls kiss, hug and } \\
\text { touch each others }\end{array}$ & YES: $66 \%$ & NO: $18.3 \%$ \\
$\begin{array}{l}\text { 3. There's no harm if boys and girls who are not } \\
\text { married have sex, if they are in love }\end{array}$ & NO: $32.4 \%$ & NO: $34.5 \%$ \\
7. A boy and a girl should have sex before & NO: $60.2 \%$ & YES: $32.8 \%$ \\
becoming engaged to see if they are made & YES: $28.3 \%$ & NO: $63 \%$ \\
for each other & NO: $69.9 \%$ & YES: $24 \%$ \\
& NO: $70.9 \%$ \\
14. It's good to have one-night stands & YES: $32.7 \%$ & YES: $30.2 \%$ \\
$\begin{array}{l}\text { 15. Boys and girls may have sex if they use means to } \\
\text { prevent pregnancy }\end{array}$ & NO: $58.5 \%$ & NO: $58.1 \%$ \\
& NO: $43.4 \%$ & YES: $38.6 \%$ \\
16. We should be in love before having sex. & YES: $80 \%$ & NO: $54 \%$ \\
\end{tabular}

enjoy it in a healthy and positive way.

The answers to the first set of questions show anon-conformity with the social and demographic pressure and an openness of the new generations. Similarly, it shows more permissiveness in flirting. Even though, parts of the negative answers were significantly linked to understanding the rules of prohibited sex (question number 2: NO 32.4\% for belief and NO 34.5\% for practice).

- Question number 1 reports the reality of Lebanese youth, their integrity in engaging in a relationship, and their true daily happening of social and peer pressure.

- Likewise, the answers of questions number 2 and 3 demonstrate an opening to a natural outlook of sexual life, (25.5\%) with reluctance on dating (51.1\%).

The relationship between both questions is moderate. Also, an important significance is showed in the percentage between beliefs and practice: $18 \%$ in belief and $78.3 \%$ in practice (Q1) and $34.2 \%$ in belief and $60.8 \%$ in practice (Q2) emphasizing on the reality of sexual engagement within Lebanese youth.

- The question number 3, inducing a more engaging sexual activity (NO 60.2\% for belief and NO $62 \%$ for practice) shows reluctance in engaging in sexual activity and attachment and fear to social sanctions toward premarital sex. The correlation between questions 3 and 7 regarding virginity is moderate and shows a $46.6 \%$ of agreeing on abstinence before marriage. Comparing beliefs and practice we find that $62.5 \%$ believe that young people shouldn't be involved in a sexual relation while only $32.4 \%$ in practice are involved.

- The answers to question 7 and 14 were proportional in belief and practice and hit a big score of $69.9 \%$ in belief and $70.9 \%$ in practice asked for a serious couple engaging in later marriage, shows the prevalence and importance of integrated collective and social pressure, a proof of conservative position and respect of one's self of sexual activity. The lower percentage of positive an- 
swers $(32.7 \%$ in belief and $30.3 \%$ in practice) shows reluctance in sex practice.

Answering YES by belief $43.4 \%$ and YES in practice $38.6 \%$ increases the precautions of safe sex to avoid pregnancy.

- Question 15 (Boys and girls may have sex if they use means to prevent pregnancy) had similar answers in belief NO $53 \%$ in practice NO 54\%, showing that pregnancy isn't the issue but not having sex is the issue.

- Question 16 (We should be in love before having sex) had significant answers about true feelings before engaging in a sexual relationship. The percentage of YES by belief $80 \%$ and YES in practice $71.1 \%$ demonstrate honesty and respect among sexually active youth.

It is important to note the highest positive answers were in Mount-Lebanon while in Beirut was medium, and in the North and the South we had a value of $2.4 \%$ and $2.7 \%$ (see Table 10 ).

Likewise, the positive answers of the girls were much lower than the boys, showing a more conservative position of girls.

Table 3 shows the obtained results after running a paired T-test on the questions of Theme 1 . We made this statistical test to compare the answers of "by belief" and "in practice" for each question. We reject the null hypothesis for the following questions " $1,2,3,7,15$ and 16" and we accept it for the question 14 . The rejection of the null hypothesis means that there is statistically significance difference between the answers of "by believe" and "in practice".

The correlation between the answers of "by belief" and "in practice" for the question of Theme 1 is moderate (see Table 3 ).

- Theme 2. The shame of premarital sex and the loss of respect from doing it.

Questions 4, 5 and 6 are related to family and social pressure, depending on demographics and backgrounds (see Table 4).

- Question number 4, addressed to the boys (A boy will not respect a girl who accepts to have sex) was answered similarly in belief (NO 28.5\%) and in practice

Table 3. Paired sample T-test results: $1^{\text {st }}$ column represents the questions of Theme $1 ; 2^{\text {nd }}$ column shows the p-value obtained after running a paired T-test on the sample; $3^{\text {rd }}$ column shows the power calculation $(1-\beta)$ for paired difference; $4^{\text {th }}$ column shows the correlation score obtained between the answers of "By belief" and "In practice"; $5^{\text {th }}$ column illustrate the decision rule of accepting or rejection of $\mathrm{H}_{0}$.

\begin{tabular}{ccccc}
\hline & p-value & $\begin{array}{c}\text { Power calculation for } \\
\text { paired difference }(1-\beta)\end{array}$ & $\begin{array}{c}\text { Correlation } \\
\text { between "by belief” } \\
\text { and "in practice" }\end{array}$ & $\begin{array}{c}\text { Decision rule } \\
\left.\text { (accept/reject of } \mathrm{H}_{0}\right)\end{array}$ \\
\hline Q1 & 0.001 & 1 & 0.602 & Reject \\
Q2 & 0.001 & 0.9816 & 0.611 & Reject \\
Q3 & 0.001 & 0.9452 & 0.538 & Reject \\
Q7 & 0.011 & 0.7206 & 0.689 & Reject \\
Q14 & 0.399 & 0.1317 & 0.702 & Accept \\
Q15 & 0.043 & 0.5268 & 0.655 & Reject \\
Q16 & 0.001 & 0.995 & 0.610 & Reject \\
\hline
\end{tabular}


Table 4. Theme 2 questions and the percentage distribution of the obtained answers.

\begin{tabular}{lcc}
\hline \multicolumn{1}{c}{ Question number } & By belief & Practically \\
\hline $\begin{array}{l}\text { 4. A boy will not respect a girl who accepts } \\
\text { to have sex. (Question for boys) }\end{array}$ & YES: $18.3 \%$ & YES: $19 \%$ \\
$\begin{array}{lc}\text { 5. Most girls who have sex before marriage } \\
\text { regret it afterwards. (Question for girls) }\end{array}$ & YES: $35.2 \%$ & NO: $26.8 \%$ \\
& NO: $15.5 \%$ & YES: $26.5 \%$ \\
$\begin{array}{lc}\text { 6. Most of the boys who have sex before } \\
\text { marriage regret it. (Question for boys) }\end{array}$ & YES: $8 \%$ & NO: $17.8 \%$ \\
& NO: $30 \%$ & YES: $6.3 \%$ \\
\end{tabular}

(NO 26.8\%) which shows an attachment of half of the male population to the social beliefs.

- Question number 5, addressed to girls (Most girls who have sex before marriage regret it afterwards) was answered almost equally in belief (YES 35.2\%) and in practice (YES 26.5\%) shows also the attachment to the roots of collective and social pressure. The small percentage of answers in belief (NO 15.5\% and in practice NO 17.8\%) identify some feminine behaviors of disposing of their rights to have an active premarital sexual life.

For questions 4 and 5, the differentiation of gender arises, involving feelings of shame and fear, an inner war within oneself, and confusion between feelings and reality. Questions 5 and 6 show the equality between genders regarding virginity.

- Question number 6 (Most of the boys who have sex before marriage regret it; question for boys) (In belief NO 30\% and in practice NO 27.4\%) shows the importance and prevalence of masculinity in our society. Most of the population will not engage in pre-marital sexual relationships (5.6\% of female and $6.3 \%$ of males). The "no-concerned" answers were the most to this set of questions.

Table 5 shows the obtained results after running a paired T-test on the questions of Theme 2. We made this statistical test to compare the answers of "by belief" and "in practice" for each question. We reject the null hypothesis for question " 6 " and we accept it for questions 4 and 5. The rejection of the null hypothesis means that there is statistically significance difference between the answers of "by believe" and "in practice".

The correlation between the answers of "by belief" and "in practice" for the questions of Theme 2 is as followed: Q4 is moderate; Q5 and Q6 is strong (see Table 5).

\section{* Theme 3. The issue of virginity.}

The following questions $8,9,10,11,12$ and 13 , raise the main issue of virginity in Lebanon (see Table 6). Lebanese men prefer to marry a girl who has abstained from sex until marriage, the main reason why women who have had premarital sex do a hymen restorative surgery.

Questions number 8, 9, 10 and 11, addressed to girls only, about virginity and flirting before marriage (Girls should remain virgins until marriage; Is the virginity the flag bearer of the honor of the girl and the family; the hymen is the 
Table 5. Paired sample T-test results: $1^{\text {st }}$ column represents the questions of Theme $1 ; 2^{\text {nd }}$ column shows the p-value obtained after running a paired T-test on the sample; $3^{\text {rd }}$ column shows the power calculation $(1-\beta)$ for paired difference; $4^{\text {th }}$ column shows the correlation score obtained between the answers of "By belief" and "In practice"; $5^{\text {th }}$ column illustrate the decision rule of accepting or rejection of $\mathrm{H}_{0}$.

\begin{tabular}{ccccc}
\hline & p-value & $\begin{array}{c}\text { Power calculation for } \\
\text { paired difference }(1-\beta)\end{array}$ & $\begin{array}{c}\text { Correlation } \\
\text { between "by belief" } \\
\text { and "in practice" }\end{array}$ & $\begin{array}{c}\text { Decision rule } \\
\left(\text { accept/reject of } \mathrm{H}_{0}\right)\end{array}$ \\
\hline Q4 & 0.814 & 0.0422 & 0.523 & Accept \\
Q5 & 0.269 & 0.1959 & 0.781 & Accept \\
Q6 & 0.008 & 0.7635 & 0.784 & Reject \\
\hline
\end{tabular}

Table 6. Theme 3 questions and the percentage distribution of the obtained answers.

\begin{tabular}{lcc}
\hline \multicolumn{1}{c}{ Question number } & By belief & Practically \\
\hline $\begin{array}{l}\text { 8. Girls should remain virgins until } \\
\text { marriage (question for girls) }\end{array}$ & YES: $52.5 \%$ & YES: $52.8 \%$ \\
& NO: $20 \%$ & NO: $16.9 \%$ \\
$\begin{array}{l}\text { 9. Is the virginity the flag bearer of the honor of } \\
\text { the girl and the family? }\end{array}$ & YES: $40.3 \%$ & YES: $41.2 \%$ \\
(question for girls) & NO: $29.6 \%$ & NO: $26.2 \%$ \\
& & \\
$\begin{array}{l}\text { 10. The hymen is the guarantor of the total faith- } \\
\text { fulness for the future husband }\end{array}$ & YES: $33.6 \%$ & YES: $34.8 \%$ \\
(question for girls) & NO: $30.3 \%$ & NO: $26.1 \%$ \\
$\begin{array}{l}\text { 11. Flirting without intercourse before } \\
\text { marriage does not affect the honor of the girl } \\
\text { (question for girls) }\end{array}$ & YES: $30.7 \%$ & YES: $28.5 \%$ \\
$\begin{array}{l}\text { 12. Restorative surgery of the hymen on the wed- } \\
\text { ding eve is a good resolution }\end{array}$ & YES: $20.7 \%$ & NO: $34.3 \%$ \\
& NO: $72.9 \%$ & YES: $16.8 \%$ \\
13. The boys should remain virgin until marriage & YES: $18.6 \%$ & NO: $72.4 \%$ \\
& NO: $30.7 \%$ & YES: $12.5 \%$ \\
\end{tabular}

guarantor of the total faithfulness for the future husband; Flirting without intercourse before marriage does not affect the honor of the girl?) had positive answers in belief and practice Q8 $=52.5 \%, 52.8 \%, \mathrm{Q} 9=40.3 \%$ and $41.2 \%, \mathrm{Q} 10=$ $33.6 \%, 34.8 \%$, Q11 = 30.7\%, $28.5 \%$.

We also received a high percentage of "NO" answers, proving a non openness about the subject and the fear of facing the issue as well as a certain level of commitment and understanding of social norms and restrictions. Women are held back from expressing their needs and tackling such a tabooed issue.

- Question number 12, about restorative surgery of the hymen, (Restorative surgery of the hymen on the wedding eve is a good resolution) we detected a level of honesty and integrity among youth. Answers were NO in belief $72.9 \%$ and NO in practice $72.4 \%$. A much lower percentage had answered YES for belief and practice $20.7 \%$ and $16.8 \%$.

- Question number 13, addressed to boys (The boys should remain virgins until marriage) had answers in belief and practice almost equal giving a NO of 
$30.7 \%$ and $35.1 \%$, showing the freedom men have in our society of being sexually active before marriage.

A consistent comparison could be made between genders in the last 2 questions, emphasizing the patriarchal issue in the society and the superior role of men. They are allowed actions whereas women are not. It is also important to note that the feminine population holds a more conservative position than masculine one.

Table 7 shows the obtained results after running a paired T-test on the questions of Theme 3 . We made this statistical test to compare the answers of "by belief" and "in practice" for each question. We reject the null hypothesis for questions " $8,9,10$ and 13" and we accept it for questions 11 and 12. The rejection of the null hypothesis means that there is statistically significance difference between the answers of "by believe" and "in practice".

The correlation between the answers of "by belief" and "in practice" for the questions of Theme 3 is as followed: Q13 is moderate; and for the rest of questions is strong (see Table 7).

Theme 4. Freedom of choice and expression concerning premarital sex.

Talking about sexuality without prejudice, with acceptance of their knowledge, practice and problems they encounter. (Questions 17-18)

Questions 17 and 18 emphasize on expressing and communicating ideas and positions regarding sexuality (see Table 8 ).

Table 7. Paired sample T-test results: $1^{\text {st }}$ column represents the questions of Theme $1 ; 2^{\text {nd }}$ column shows the p-value obtained after running a paired T-test on the sample; $3^{\text {rd }}$ column shows the power calculation $(1-\beta)$ for paired difference; $4^{\text {th }}$ column shows the correlation score obtained between the answers of "By belief" and "In practice"; $5^{\text {th }}$ column illustrate the decision rule of accepting or rejection of $\mathrm{H}_{0}$.

\begin{tabular}{ccccc}
\hline & p-value & $\begin{array}{c}\text { Power calculation for } \\
\text { paired difference }(1-\beta)\end{array}$ & $\begin{array}{c}\text { Correlation } \\
\text { between "by belief” } \\
\text { and “in practice" }\end{array}$ & $\begin{array}{c}\text { Decision rule } \\
\left.\text { (accept/reject of } \mathrm{H}_{0}\right)\end{array}$ \\
\hline Q8 & 0.001 & 0.909 & 0.721 & Reject \\
Q9 & 0.012 & 0.7146 & 0.724 & Reject \\
Q10 & 0.006 & 0.7792 & 0.779 & Reject \\
Q11 & 0.114 & 0.3521 & 0.807 & Accept \\
Q12 & 0.149 & 0.3028 & 0.636 & Accept \\
Q13 & 0.001 & 0.9574 & 0.535 & Reject \\
\hline
\end{tabular}

Table 8. Theme 4 questions and the percentage distribution of the obtained answers.

\begin{tabular}{lcc}
\hline \multicolumn{1}{c}{ Question number } & By belief & Practically \\
\hline $\begin{array}{l}\text { 17. I express my opinion regarding sexuality freely in } \\
\text { society. }\end{array}$ & YES: $68.8 \%$ & YES: $58.6 \%$ \\
& NO: $27.6 \%$ & NO: $34.6 \%$ \\
$\begin{array}{l}\text { 18. I express my opinion regarding sexuality freely } \\
\text { with my family. }\end{array}$ & YES: $51.9 \%$ & YES: $43.2 \%$ \\
\end{tabular}


(I express my opinion regarding sexuality freely in society; I express my opinion regarding sexuality freely with my family). Affirmative answers of question 17 of $68.8 \%$ by belief and $58.6 \%$ in practice, demonstrate a more free expression within one's social circle made of friends of same age, but less positive answers within the family circle ( $51.9 \%$ by belief and $43.2 \%$ practically) engage undoubtedly into family and social repression.

Table 9 shows the obtained results after running a paired T-test on the questions of Theme 4. We made this statistical test to compare the answers of "by belief" and "in practice" for each question. We reject the null hypothesis for questions " 17 and 18". The rejection of the null hypothesis means that there is statistically significance difference between the answers of "by believe" and "in practice".

The correlation between the answers of "by belief" and "in practice" for the questions of Theme 4 is strong (see Table 9).

It is important to note that population in Mount Lebanon showed an openness in sexual activities and more freedom in expressing themselves. The positive answers are the highest in Mount-Lebanon, while lesser in Beirut, and very low in the North and the South (see Table 10).

Figure 1 and Figure 2 illustrate visually the difference between "By beliefs" and "In practice". By comparing them, we could see that the "NO" answers "By practice" are higher than "By beliefs". The reason might be an emotional conflict and reluctance between their desires and their practices, underlying the social norms. The link between the belief of practicing sexual and actually practicing sexuality is contradictory.

\section{Discussion}

Studies show that young Lebanese students have different attitudes and dimensions toward sexuality. The information and the knowledge they receive about it is limited [11].

Introducing the Sexual Education in the renovated curricula of 1998 was objected by many socio-political and religious authorities in Lebanon [12]. In our society, children aren't engaged in open communication at home. Several important matters are not discussed and may lead to apprehensiveness in future relationships [13] [14].

Table 9. Paired sample T-test results: $1^{\text {st }}$ column represents the questions of Theme $1 ; 2^{\text {nd }}$ column shows the p-value obtained after running a paired T-test on the sample; $3^{\text {rd }}$ column shows the power calculation $(1-\beta)$ for paired difference; $4^{\text {th }}$ column shows the correlation score obtained between the answers of "By belief" and "In practice"; $5^{\text {th }}$ column illustrate the decision rule of accepting or rejection of $\mathrm{H}_{0}$.

\begin{tabular}{ccccc}
\hline p-value & $\begin{array}{c}\text { Power calculation for } \\
\text { paired difference }(1-\beta)\end{array}$ & $\begin{array}{c}\text { Correlation } \\
\text { between "by belief” } \\
\text { and “in practice" }\end{array}$ & $\begin{array}{c}\text { Decision rule } \\
\left(\text { accept/reject of } \mathrm{H}_{0}\right)\end{array}$ \\
\hline Q17 & 0.001 & 1 & 0.728 & Reject \\
Q18 & 0.001 & 1 & 0.749 & Reject \\
\hline
\end{tabular}


Table 10. Significance of high percentage of some YES answers by region.

(a)

\begin{tabular}{cccccccccc}
\hline \multirow{5}{*}{} & & \multicolumn{2}{c}{ Q1 } & \multicolumn{2}{c}{ Q2 } & \multicolumn{2}{c}{ Q3 } & \multicolumn{2}{c}{ Q4 } \\
\cline { 3 - 10 } Beirut & & Yes & No & Yes & No & Yes & No & Yes & No \\
\hline \multirow{3}{*}{ Mount Lebanon } & Belief & $18.06 \%$ & $0.74 \%$ & $16 \%$ & $2.3 \%$ & $10.3 \%$ & $8.5 \%$ & $2.2 \%$ & $2.4 \%$ \\
& Practice & $17.2 \%$ & $1.6 \%$ & $14.8 \%$ & $3.3 \%$ & $8.6 \%$ & $10.2 \%$ & $2.1 \%$ & $2.2 \%$ \\
& Belief & $39.92 \%$ & $3.6 \%$ & $35.6 \%$ & $8 \%$ & $20.77 \%$ & $22.75 \%$ & $3.7 \%$ & $6.1 \%$ \\
\cline { 3 - 10 } North & Practice & $38.4 \%$ & $3.9 \%$ & $33.3 \%$ & $8.7 \%$ & $18.2 \%$ & $24.1 \%$ & $3.3 \%$ & $5.8 \%$ \\
& Belief & $5.8 \%$ & $0.4 \%$ & $4.1 \%$ & $2.1 \%$ & $2.4 \%$ & $3.8 \%$ & $0.4 \%$ & $0.58 \%$ \\
& Practice & $5.5 \%$ & $0.8 \%$ & $4.8 \%$ & $1.44 \%$ & $2 \%$ & $4.3 \%$ & $0.58 \%$ & $0.44 \%$ \\
& Belief & $16.8 \%$ & $8.06 \%$ & $6.6 \%$ & $18.2 \%$ & $3 \%$ & $9.17 \%$ & $1.54 \%$ & $2.1 \%$ \\
& Practice & $13.02 \%$ & $10.7 \%$ & $4.7 \%$ & $19 \%$ & $2.8 \%$ & $20.92 \%$ & $1.55 \%$ & $1.9 \%$ \\
& Belief & $1.9 \%$ & $0.3 \%$ & $1.6 \%$ & $0.6 \%$ & $0.3 \%$ & $1.9 \%$ & $0.3 \%$ & $0 \%$ \\
& Practice & $1.6 \%$ & $0.5 \%$ & $1.4 \%$ & $0.7 \%$ & $0.6 \%$ & $4.2 \%$ & $0.3 \%$ & $0 \%$ \\
\hline
\end{tabular}

(b)

\begin{tabular}{cccccccccc}
\hline & & \multicolumn{2}{c}{ Q5 } & \multicolumn{2}{c}{ Q7 } & \multicolumn{2}{c}{ Q8 } & \multicolumn{2}{c}{ Q10 } \\
\cline { 3 - 9 } & & Yes & No & Yes & No & Yes & No & Yes & No \\
\hline \multirow{2}{*}{ Beirut } & Belief & $2 \%$ & $1.5 \%$ & $6.6 \%$ & $11.8 \%$ & $2.1 \%$ & $2 \%$ & $3.7 \%$ & $6.5 \%$ \\
& Practice & $1.7 \%$ & $1.3 \%$ & $5.2 \%$ & $12.7 \%$ & $2.9 \%$ & $1.1 \%$ & $4.2 \%$ & $5.7 \%$ \\
Mount & Belief & $3.6 \%$ & $2.7 \%$ & $16.2 \%$ & $26.7 \%$ & $7.3 \%$ & $2.9 \%$ & $3.7 \%$ & $6.1 \%$ \\
Lebanon & Practice & $2.9 \%$ & $2.8 \%$ & $14.6 \%$ & $26.7 \%$ & $6 \%$ & $5.54 \%$ & $12.5 \%$ & $13.3 \%$ \\
& Belief & $0.7 \%$ & $0.14 \%$ & $2.1 \%$ & $1.4 \%$ & $1 \%$ & $0.4 \%$ & $0.4 \%$ & $0.58 \%$ \\
& Practice & $0.6 \%$ & $0.28 \%$ & $1.8 \%$ & $4.2 \%$ & $1 \%$ & $0.44 \%$ & $2.3 \%$ & $1 \%$ \\
South & Belief & $1.8 \%$ & $1.1 \%$ & $2.7 \%$ & $22.3 \%$ & $3.2 \%$ & $1 \%$ & $1.54 \%$ & $2.1 \%$ \\
& Practice & $1.25 \%$ & $1.3 \%$ & $1.7 \%$ & $22.2 \%$ & $2.4 \%$ & $1.1 \%$ & $13 \%$ & $4.2 \%$ \\
& Belief & $0 \%$ & $0 \%$ & $0.14 \%$ & $1.94 \%$ & $0.28 \%$ & $0 \%$ & $0.3 \%$ & $0 \%$ \\
\hline & Practice & $0 \%$ & $0 \%$ & $0.14 \%$ & $2 \%$ & $0.14 \%$ & $0 \%$ & $0.28 \%$ & $0.3 \%$
\end{tabular}

(c)

\begin{tabular}{|c|c|c|c|c|c|c|c|c|c|}
\hline & & \multicolumn{2}{|c|}{ Q11 } & \multicolumn{2}{|c|}{ Q13 } & \multicolumn{2}{|c|}{ Q17 } & \multicolumn{2}{|c|}{ Q18 } \\
\hline & & Yes & No & Yes & No & Yes & No & Yes & No \\
\hline \multirow{4}{*}{ Mount Lebanon } & Belief & $5.5 \%$ & $4.9 \%$ & $2.1 \%$ & $2 \%$ & $14.38 \%$ & $4.09 \%$ & $11 \%$ & $7.47 \%$ \\
\hline & Practice & $4.5 \%$ & $1.8 \%$ & $1.3 \%$ & $2.7 \%$ & $12.13 \%$ & $5.64 \%$ & $9.17 \%$ & $8.6 \%$ \\
\hline & Belief & $15.4 \%$ & $13 \%$ & $4.8 \%$ & $5.4 \%$ & $32.59 \%$ & $9.73 \%$ & $25.4 \%$ & $16.92 \%$ \\
\hline & Practice & $14.1 \%$ & $12.8 \%$ & $2.34 \%$ & $9.1 \%$ & $12.97 \%$ & $12.15 \%$ & $4.53 \%$ & $20.59 \%$ \\
\hline \multirow{2}{*}{ North } & Belief & $2.3 \%$ & $1.3 \%$ & $0.8 \%$ & $0.6 \%$ & $4.26 \%$ & $1.69 \%$ & $4.4 \%$ & $1.42 \%$ \\
\hline & Practice & $2.2 \%$ & $1 \%$ & $0.6 \%$ & $0.84 \%$ & $4.26 \%$ & $1.69 \%$ & $\%$ & $\%$ \\
\hline \multirow{2}{*}{ South } & Belief & $7 \%$ & $13.5 \%$ & $1.9 \%$ & $2.3 \%$ & $12.86 \%$ & $10.86 \%$ & $9.31 \%$ & $14.41 \%$ \\
\hline & Practice & $6.2 \%$ & $13.1 \%$ & $1.7 \%$ & $1.8 \%$ & $11.84 \%$ & $10.88 \%$ & $7.75 \%$ & $14.97 \%$ \\
\hline \multirow{2}{*}{ Bekaa } & Belief & $0.14 \%$ & $0.18 \%$ & $0.14 \%$ & $0 \%$ & $0.56 \%$ & $1.12 \%$ & $0.56 \%$ & $1.13 \%$ \\
\hline & Practice & $0.14 \%$ & $4.5 \%$ & $0 \%$ & $0.14 \%$ & $0.3 \%$ & $0 \%$ & $0 \%$ & $0 \%$ \\
\hline
\end{tabular}




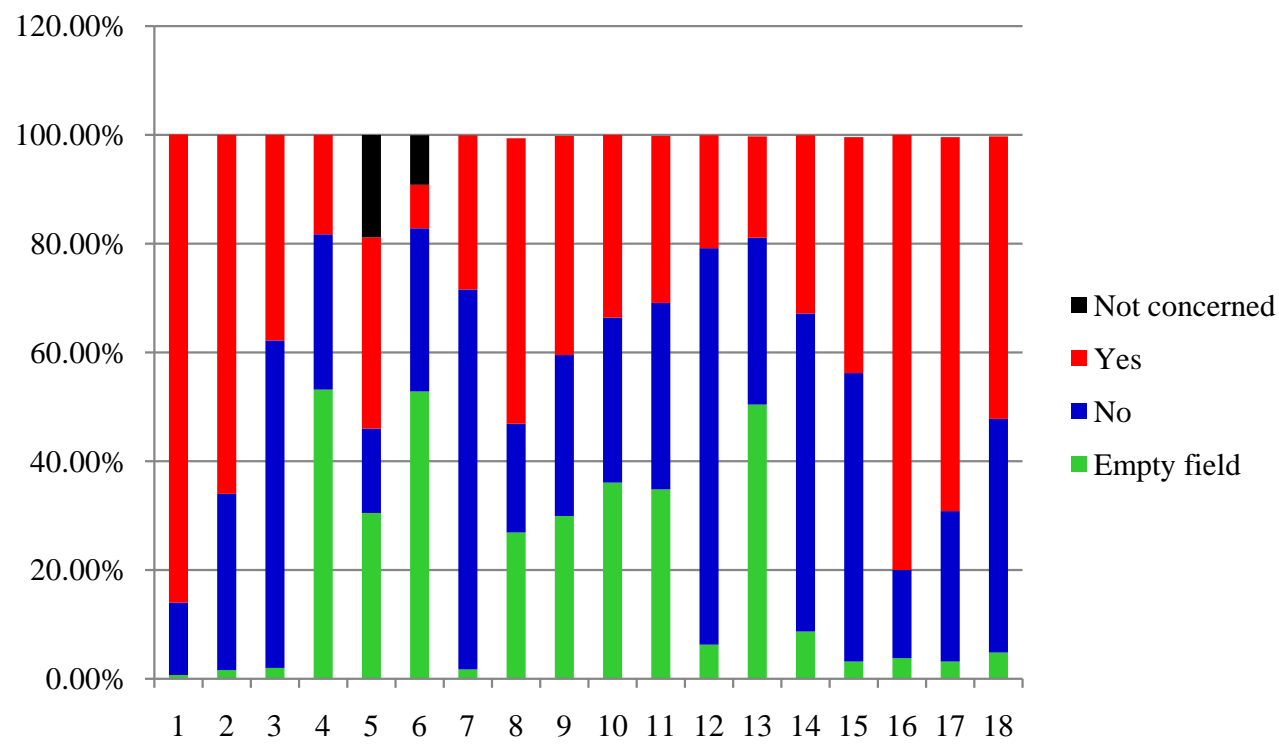

Figure 1. The percentage distribution for "By beliefs" answers' for the 18 questions. The horizontal axis represents the question number from 1 to 18. The vertical axis represents the percentage distribution for each answer (green color for "empty field", blue color for "No", red color for "Yes" and black color for "Not concerned").

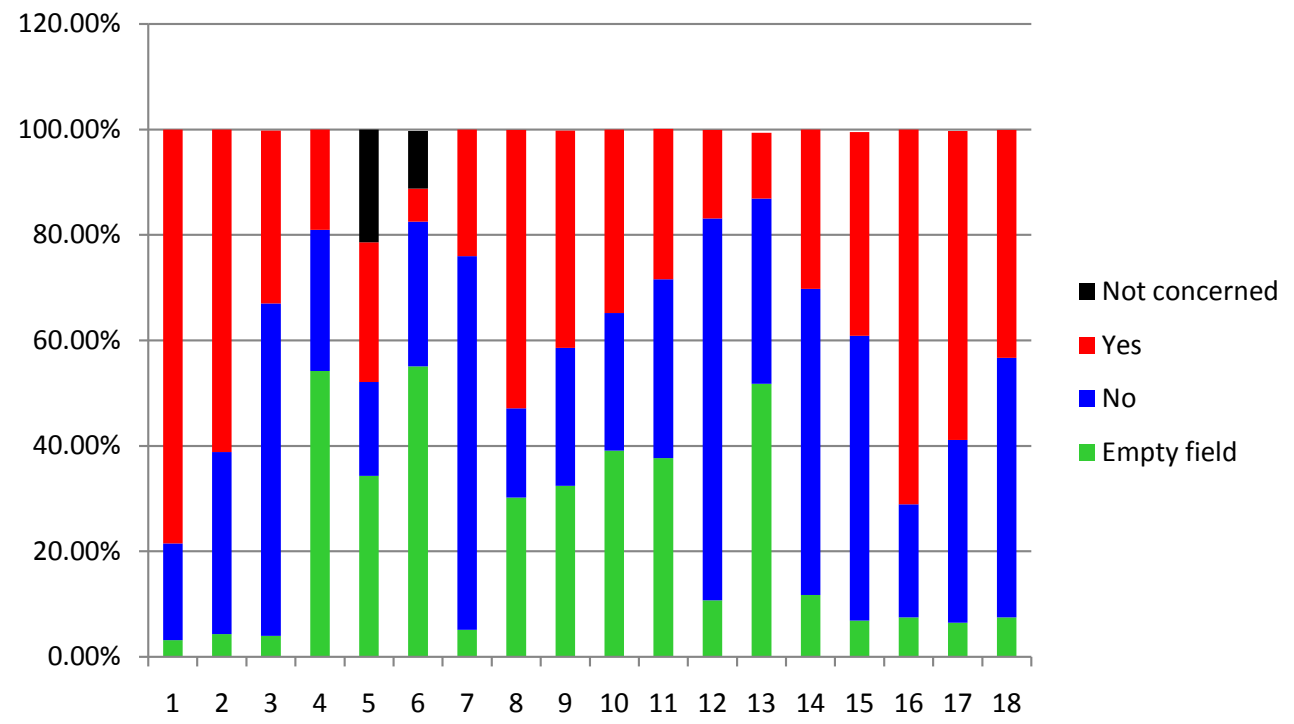

Figure 2. The percentage distribution for "In practice" answers' for the 18 questions. The horizontal axis represents the question number from 1 to 18 . The vertical axis represents the percentage distribution for each answer (green color for "empty field", blue color for "No", red color for "Yes" and black color for "Not concerned").

Lack in sexual information and diversity of opinions among youth has lead to either sexual freedom or prevalence with social and religious norms. The aim of youth is to maintain the conformity with the family honor [15]. Loyalty towards family is a "due" among all religions [16].

Studies show that being sexually active before marriage creates to Men and Women a feeling of loss in their sexual identity [17]. We could also add the doubt and suspicion created among them. Even though, having sex is a natural, 
healthy need for both genders; even if it happens before marriage. However, the issue of virginity for women in Lebanon and Arab societies has always been sacred. It rises among girls. They engage in anal and oral sex not to jeopardize their reputation in order to be virgins at their marriages. This new generation is more open to the girl freedom of sexuality. However the study proves otherwise due to the fear of being looked down upon, the fear of bad reputation in the society [18].

Therefore, the restorative surgery of the hymen is a current issue occurring in Lebanon.

This fluctuation between beliefs and practices identifies the antagonist behaviors between the conservative society and one's healthy outlook of life [19].

The women of the Arab societies are manipulated and oppressed by men. They have no right to speak their minds and end up obeying their husbands to please them.

Premarital sex isn't allowed. Premarital sexual activity may lead to sanctions from the girl's family, ending up in punishment for both her and the man involved with her [20].

However, research done by Dr. Khair-Badawi [21] indicates that "unmarried women lead a more satisfactory sexual life than married women who hadn't engaged in premarital sex...”

Most married women aren't sexually satisfied because of a lack of communication with their husbands. They are bonded with the traditional behavior of being a "follower". This behavior could be explained by the necessity women have to be secured within the family and the marriage constitution [22].

On the other hand, Bouhdiba, A. in his book "La sexualité en Islam" (p. 22) defines:

Sexuality as a deployment of the intensity of life. Islam rejects the notion of impurity of women. The focus is on the opposition of the pure and impure for both sexes. It is sex that begets impurity of man as well as woman. This theme of impurity consecutive to the organic practice of sexuality is central to Islam. It distinguishes between lawful and unlawful relationships and teaches the art to remain pure as long as possible when the impurity arises (p. 23).

Many young men and women make their own choices and commitment independently from their background beliefs and social pressure. They develop their own visibility of their active sexual life. They are aware of risks of sexual intercourse and protect themselves and their partners.

\section{Limits of the Study}

The study was anonymous. However, it led to the refusal of answering specific questions or even the entire questionnaire (5\%) which could have an influence on the reliability of the answers. We also question about the hesitation and sincerity of our population.

The study was limited due to the rules and regulations of universities on religion (how religion could affect beliefs and practices.) It is the reason why reli- 
gion and social issues were discussed only globally.

\section{Conclusions}

Young Lebanese have a huge need of information and guidance regarding sexual education. They are in search for answers because the subject is a taboo. The mentality of our society does not reflect the reality of sexual activities and practices among youth. Are we showing a skewed façade of our society [23]?

There is a lot to be done in Lebanese society about sexual knowledge. It starts at home and continues at school. How do we expect the young adults to be prepared for life and be able to raise a family with a lack of information, education and communication regarding sexuality [24]?

Where is anticipation? Where is the discipline? When we mention pre marital sexual life, are we talking about a lack of morality? Disrespect to our family and society? Are we betraying our religion? Are we destroying our ancestral and civilizations? Socio-cultural considerations?

It is not about morality, it is something which all Lebanese people need: early learning and education, openness, a neat and real communication of sexual life, being a natural part of life, with honesty and transparency [25].

In Lebanon and Arab countries, sex is taboo. Pre-marital sex is still considered borderline and illegal at the official level. As an example of how close-minded the Lebanese official norms are, the Article 534 of the Lebanese penal code states that "sexual intercourse contrary to nature" is punishable for up to one year in prison. Homosexuality is illegitimate and criminalizes the meaning of sexuality, making it unclear to teens whom are lost between the distribution of mentalities and social opinions. Are we based on scientific and biological contents or on the religious values and social ones?

How do we build future couples and healthy marriages if they are starting their couple with fear and not with respect of their love and plans? Are they well prepared for the marital sexuality? Is the concept of marital sexuality differs in Europe, the US and the Arab countries?

Marital sexuality expresses the union and the depth of feelings between husband and wife as well as giving birth to children and educating them. It is the relational bond of sexuality.

A couple experiences pleasure and enjoyment of the body and spirit through sexual intercourse together. The man and woman create a bond which unites them and allows them to express and deepen the love between one another. Sexual intercourse forms a bond of companionship between man and woman.

\section{References}

[1] Birraux, A. (1990) L'adolescent face à son corps. In: Michel, A., Ed., Editions Universitaires, Paris.

[2] Bouhdiba, A. (1975) La sexualité en Islam France Pud. Paris.

[3] Brenot, P. (2003) Le sexe et l'amour. In: Jacob, O., Ed., Paris.

[4] Pelège, P. and Picod, C. (2006) Éduquer à la sexualité Dunod. Paris. 
[5] Borenstein, E. (2009) Sexual Revolution in Bolshevik Russia. Journal of the History of Sexuality, 18, 514-517.

[6] Kurt Conklin, M.M. (2012) Adolescent Sexual Behavior: Demographics, Advocates for Youth, FACTS.

http://www.advocatesforyouth.org/publications/publications-a-z/413-adolescent-se xual-behavior-i-demographics

[7] Aspden, R. (2015) Headscarves and Hymens: Why the Middle East Needs a Sexual Revolution by Mona Eltahawy-Review.

http://www.theguardian.com/books/2015/jun/12/headscarves-and-hymens-why-the -middle-east-needs-a-sexual-revolution-mona-eltahawy-review

[8] Yammine, A. and Clément, P. (2014) Horizon of Human Sex Education in Lebanon. Esera.

[9] Shaheen, K. (2014) Breaking Taboos to Promote Healthy View of Sexuality. http://www.dailystar.com.lb/News/Lebanon-News/2014/Sep-20/271331-breaking-ta boos-to-promote-healthy-view-of-sexuality.ashx

[10] (2011) The Top 5 Misconceptions about Sex in Lebanon. https://now.mmedia.me/lb/en/reportsfeatures/the_top_5_misconceptions_about_se $\underline{\mathrm{x} \_ \text {in_lebanon }}$

[11] Yammine, A., Khalil, I. and Clement, P. (2011) Sex Education in Lebanon and France. ESERA.

[12] Badawi, M.T.K. (2000) Le désir amputé. vécu sexuel de femmes libanaises té d'Oxford L'Harmattan, Paris.

[13] (2011) Lack of Sex Education in Lebanese Schools Poses Risks: Experts.

[14] Reproductive and Sexual Health Awareness Education and Family Planning Service Delivery for the Lebanese Army (2011).

http://www.unfpa.org.lb/PROGRAMME-AREAS/Reproductive-Health-and-Rights/ Reproductive-and-Sexual-Health-Awareness-Education.aspx

[15] Darkmoon, L. (2013) Darkmoon.

[16] Ghazi, A. (1997) Lebanon's Culture. http://www.ghazi.de/society.html

[17] Skerry, P. (2015) American Interest. http://www.the-american-interest.com/2015/10/03/does-the-arab-world-need-a-sex ual-revolution/

[18] Wernvik, L. (2013) Lebanese Youth Want to Lift the Taboo of Sex. http://www.iloubnan.info/social/77496/Lebanese-youth-want-to-lift-the-taboo-of-s $\underline{\mathrm{ex}}$

[19] Abdallah, S.A. (2012) Sexism: The Lebanese Take on Premarital Sex. http://sexisminlebanon.blogspot.com/

[20] Cohen, N.L. (2012) How the Sexual Revolution Changed America Forever. http://www.alternet.org/story/153969/how_the_sexual_revolution_changed_americ a_forever

[21] Fisher, M. (2012) The Real Roots of Sexism in the Middle East (It's Not Islam, Race, or "Hate").

http://www.theatlantic.com/international/archive/2012/04/the-real-roots-of-sexism -in-the-middle-east-its-not-islam-race-or-hate/256362/

[22] Kaddour, A., Alameh, H., Melekian, K. and Shareef, M.E. (2002) Abortion in Lebanon: Practice and Legality? http://www.theaproject.org/node/123

[23] Mandour, S. (2012) Potential Change in Media Discourse on Sexuality in Lebanon. http://reutersinstitute.politics.ox.ac.uk/publication/potential-change-media-discour se-sexuality-lebanon 
[24] Dhumières, M. (2011) Lebanon's Awakening: Let's Talk about Sex, Say Lebanese Sex Therapists.

http://www.albawaba.com/lebanons-awakening-let\%E2\%80\%99s-talk-about-sex-sa y-lebanese-sex-therapists-379561

[25] IPPF UWUGIaY (2009) Rapid Assessment of Sexual and Reproductive Health and HIV Linkages.

http://www.who.int/reproductivehealth/topics/linkages/RASlebanon.pdf

Submit or recommend next manuscript to SCIRP and we will provide best service for you:

Accepting pre-submission inquiries through Email, Facebook, LinkedIn, Twitter, etc. A wide selection of journals (inclusive of 9 subjects, more than 200 journals)

Providing 24-hour high-quality service

User-friendly online submission system

Fair and swift peer-review system

Efficient typesetting and proofreading procedure

Display of the result of downloads and visits, as well as the number of cited articles

Maximum dissemination of your research work

Submit your manuscript at: http://papersubmission.scirp.org/

Or contact health@scirp.org 